\title{
Egypt and It's Implication for Modernizing of Education in Indonesia
}

\author{
Muhamad Murtadlo ${ }^{1}$, Husen Hasan Basri ${ }^{2}$, Qawaid ${ }^{3}$ \\ \{tadho25@gmail.com¹, hhasanbasri@yahoo.com², qowaidbmasyhuri@gmail.com³
}

The Office of Religious Education Center, The Ministry of Religion Affair of Republic Indonesia ${ }^{1,2,3}$

\begin{abstract}
This article will describes the role model of modernization of education in Egypt and it's implication for education in Indonesia. This research is done by a qualitative research approach. The collecting data is done by three techniques, namely interview, observation, and document review. This research conclude Firstly, education in Egypt, especially at Al Azhar University teaches Islam wasatiyah which corresponds to the culture of Indonesia's diversity. A moderate outlook becomes a trademark of Al Azhar University alumni. This alumni model is needed to guard the diversity in Indonesia as one of the pillars of the unitary state of the Republic of Indonesia. Secondly, Al Azhar University alumni have contributed significantly to advancing Islamic moderatism in Indonesia. It is realized with the alumni's gait in advancing Islamic education such as madrassas and Islamic colleges that prioritize moderate Islam.
\end{abstract}

Keywords: Egypt, Indonesian Student, Modernization of Education

\section{Introduction}

Every year, thousands of Indonesian students apply for admission to the al-Azhar University of Egypt. In 2014, 3200 prospective students apply for selection to study in the country. This data shows that the interest of Indonesian youth to seek knowledge in Egypt is quite high. After the selection, there are 512 applicants accepted. The Egyptian government requires that prospective students from Indonesia be informed by the Ministry of Religious Affairs. Prospective students who come directly to Al Azhar Campus without going through the Ministry of Religious Affairs certainly get various administrative difficulties. By 2017, there are about 1500 prospective students declared accepted to be prospective students in Egypt.

In the past decades, we can also find scholars who after studying from Mecca they continued to study in Cairo Egypt, precisely at the University of al-Azhar. Some big names like Muhammad Arsyad, Sayyid Abd al-Shamad al-Palimbangi, Abd al-Rahman al-Batawi, and Abd al-Wahab al-Bugis are some Indonesian scholars who intend to increase knowledge in Cairo. Among the representations of the highly prolific Al-Azhar students is Muhammad Idris Abd alRauf al-Marbawi Al-Azhari.

Al Azhar University in Cairo has produced many prominent clerics known to the public, especially for the people of Indonesia. The figures from Indonesia who have graduated fromThe Al Azhar University as like HM Quraish Shihab, Ph. D, Zakiah Darajat Ph. D, Huzaemah T. Yanggo, Azman Ismail (Imam of Great Mosque Baiturrahman Banda Aceh). Form the young people later emerged like Muhlis Hanafi, Ph. D (Head of Lajnah Pentashihan Mushaf Al 
Qur'an), Abdul Ghofur Maemun Ph. D (Pesantren Sarang Rembang), Muhammad Zainul Majdi, $\mathrm{Ph}$. D (the Provincial Governor of NTB), and many more.

Later, the leadership of Egypt in the world of modernization began to be doubted by the failure of democracy in Egypt. It was marked by the overthrow of civil government by the soldiers of the country under the current Egyptian President As Sisi. The case of social transformation in Egypt is one phenomenon that happened in several Muslim countries that transform into new models of Moslem countries such as Turkey and Iran. These countries managed to get out of the social and political crisis in the modern world and willing to become competitive nations in the new world.

Besides, for the Indonesians students continuing study abroad will have several joys and sorrows. They will be experienced facing obstacles while study there. Living among students from many countries will give them experience in the facing cultural differences, an in-process study in class the will meet different lecture systems, security that are still found in several vulnerabilities, and some other obstacles. Many cultures existed in Indonesia in similar conditions with Egyptian society. The lecture system was not much the same. For example, some lecturers do not require students to take an active presence in lectures. Lectures are often given in one direction and lack of discussion. If students are less able to adapt to the existing education culture of Egypt then most of them encounter many problems. The other issues, currently in Egypt still often appear security vulnerabilities such as the explosion of bombs in certain locations in that country. Conversely, if they can adapt to the environment there then some obstacles can be passed well.

To mapping the various problems faced by Indonesians students and also to increase their insight in Egypt, many students of Indonesia helped by many institutions in this country, both governmental and non-government agencies that make attention in the study of religion. Among them are elements of the embassy and the structure under it, student organizations both are regional and that is oriented special interest and so forth. The existence of various institutions is very important in helping students to adapt to and understanding the situation.

To wacth the implication of model educational of Egypt, this research will focus on the role of al azhar student and alumni in the development of Indonesia modern. Many questions will be answered: What is the reason of Indonesia Student study to Al Azhar University and what the role of Al Azhar Egypt's alumni in developing Indonesia's education.

The results of this research are useful : in reading opportunities for students and prospective students to preparing and implementing lectures in Egypt in order to be able to learn well; in making policy for the Ministry of Religious Affairs for coaching and mentoring students and alumnus along and after back to homeland; For Research and Development Research and Training is useful in conducting further research problems of students studying abroad and in developing and training prospective students who are studying abroad.

\section{Literature review}

Some research focus on Egypt and its relatied with Indonesia have be done by some scholar. In this chapter, I will mention the like Giora eliraz, Arief Sukino, Usman and Khoirudin Nasution.

Giora Eliraz in his article "The Islamic Reformist Movement in the Malay-Indonesian world in the First Four Decades of the 20'h Century: Insights Gained from a Comparative Look

at Egypt" mentions that even though the reform movement in Melayu-Indonesia was inspired 
and came from Egypt, but the reform movement in Malayu-Indonesia was much more successful than in Egypt itself. He thinks historically, the pluralism in Malay-Indonesian culture has existed in this region. So when Islam comes, it's adapt to the local community has used various techniques and ways. So when the renewal of Islamic thought from Egypt came, it was easily accepted by Indonesian people. The modernization inspired by Egypt became one of the variants of Islam thought that colored by the plurality [1].

Arief Sukino mentioned that Egypt is a moderate Islamic model because Al-Azhar educational institutions have succeeded in establishing a spirit of harmony, modernity, and tolerance among different groups, both inside and outside of Islam. The modernities here are: Firstly, to ensure that the ideology of Islamic moderation will not violate or transcend the primary lines (tsawâbit) contained in the teachings of Islam. Secondly, ease tolerance by spreading peace on earth and establishing an inter-religious dialogue. The reason is that religious dissent is an entity that should be protected and respected by the slogan 'qabûl al-akhar' (accept others) [10].

Usman in his writings "Deradicalization Model of Terrorism Prisoners Comparative Study of Deradicalisation in Yemen, Saudi Arabia, Singapore, Egypt, and Indonesia." The book mentions that the deradicalization as an effort to reduce terrorism in Egypt is not as much as the Indonesian government has done. The deradicalization efforts in Egypt are not performed on individual prisoners but are directed at groups or organizations to de-radicalize their groups, while the Indonesian approach in deradicalization appears more comprehensive. The deradicalization design in Indonesia has four approaches, namely reeducation, rehabilitation, resocialization, and reintegration [2].

Khorudin Nasution, in his article "The Egyptian Islamic Militant Movement and its Relevance to Indonesian Islamic Politics: The Study of Muslim Brotherhood Movement states that the development of the influence of the Ikhwan ul Muslimin in Indonesia" mentions three reasons why the Ikhwanul Muslimin inspiring some of the Islamic movement in Indonesia. Firstly, purely just a desire to develop the movement, because there may be demands from the doctrine of his movement. Secondly, the possibility is due to dissatisfaction with the policy of the government in power. Third, because the view of moral depravity is increasingly engulfing Indonesian Muslims. However, Khorudin concludes that the influence of the negative Egyptian movement is likely the revolution of Islam in Indonesia. According to him, Indonesian Muslims are syncretic and very accommodating. This attitude is generally difficult to do revolution [3].

\section{Research method}

This research is done by a qualitative research approach. this research focused on mapping the contribution of Egyptian education in the modernizing of Islamic education in Indonesia. The collecting data is done by three techniques, namely interview, observation, and document review. The Interviews were conducted with the students studying at Al Azhar University today, the Indonesian government official in Egypt, the board of Indonesian student organization in Egypt. The observations made on the life of Indonesian students in Cairo in various areas of life such as on-campus, in place of student activities, and so forth. The documents reviewed are among others the documents on student activities, student conditions, books related to the life of Indonesian students in Egypt. The data will be examined with a historical approach and the important role of Egyptian education for Indonesia. 


\section{Results and discussion}

\subsection{History of relations Indonesian and Egypt}

The relationship between Indonesia and Egypt have been longstanding. A book describes the dynamics and chronology of both country happen long before the Indonesian state was formed. The book is titled Far in the Eyes of the Heart: The Portrait of Egyptian Indonesia Relations (2010) edited by AM Fachir. The book has been published by the Indonesian Embassy of Egypt. This book contains 4 chapters comprising the Egypt-Indonesia Relations in PreIndonesia independence (1945); Egypt-Indonesia Relations in President Sukarno era; EgyptIndonesia relations of President Suharto era; and the Egypt-Indonesia Relations post Indonesia reform era ${ }^{1}$.

Long before the pre-Indonesia Independence era, the earliest moment marked and could be mentioned even long before Islam came, that is, when the Egyptians began to use lime originating from Barus, an area of the archipelago for the sake of preservation of mummies in Egypt. This debcrition is the earliest trace marking the existence of Indonesian relation with Egypt. This relationship became more apparent when Islam came with the presence of Shi'iteism from Egypt, which at that time was the authority of the Bani Fathimiyah, in the kingdom of Perlak in East Aceh (now).

Egypt-Indonesia relations began to appear bright when the 19th century, where some works of archipelago scholars such as the work of cleric Sheikh Nawawi al bantani began published in Egypt. The presence of Muhammad Abduh has marked the rise of Islamic intellectualism based in Egypt. The next time some of the archipelago scholars who firsty were focused on religious studies in Makkah and Medina and then continued to Egypt after sheikh Muhammad Abduh started the Islamic education reform movement. The idea of educational modernization sponsored by Egyptian scholars brought to the archipelago was brought by the disciple of shaykh Ahmad Khatib Minangkabau, a minang boy named Sheikh Tahir Jalaludin who later spread the idea of Islamic thought renewal in South East Asia. Tahir Jalaluddin spreaded the renewal Islamic Thought through Al Imam magazine published in Singapore (1907) and builded the Madrasah Al Iqbal Islamiyah in Singapore.

When Indonesia proclaimed national independent, Egypt was the first country to recognize Indonesian independence. By chance Egypt was then the leader of the Arab League that was able to encourage Arab countries to immediately provide support for Indonesia's independence. Through intensive communication between the Indonesian student associations in Egypt and the Egyptian Government at that time, on 1 June 1947 the Egyptian Cabinet under the leadership of Prime Minister Mahmoud Fahmi Nokrasyi issued a decree formally recognizing Indonesia's Independence.

Since then the relationship between Egypt and Indonesia is like a sister country trying to improve each other. Both nation adopt the idea of modern state. Moreover, the establishment of an independent Indonesian state was born thanks to the share of Egyptian recognition given to Indonesia. The same idea to become modern state implementated in formulating of Institution of Islamic Education. Until now, the development of modern Islamic education in Indonesia is much oriented to Egypt. Especially in higher education, IAIN and its development became State

\footnotetext{
${ }^{1}$ See Fachir, AM. Jauh di Mata Dekat di Hati: Potret Hubungan Indonesia Mesir. Cairo: Kedutaan Besar Republik Indonesia Mesir, 2010
} 
Islamic University (UIN) in curriculum development, the development of study program and faculty mostly refers to Al Azhar University of Egypt.

\subsection{Indonesia-Egypt cooperation in education and culture}

Until now, thousands of Indonesian students studying abroad, whether studying in Asia, America, Europe, Africa, also the Middle East. Some countries that became the main goal of Indonesian students studying abroad, is the Arab Republic of Egypt. Al Azhar University in Cairo became a favorite college of Indonesian students in the country. The data (2014) shows that Indonesian students studying in Egypt reached about 3800 people. The majority of Indonesian students attended Al Azhar University, and only a few of them attended other universities in Egypt, such as Cairo University.

There are many reasons why Indonesian students prefer to study in Egypt, compared to other Middle Eastern countries. One of the best motivations, so they prefer to choose Al Azhar University, is because it's the oldest institution of higher education that has stood for more than 1000 years. Learning in the land of Egypt not only learn the treasures of the old civilization of the world, but also the Al Azhar University is also recognized as an educational institution that produces thousands of alumni who take part in the world with moderate value. Egypt is also known as the country of the prophets, as the Prophet Moses was born, the Prophet Yusuf became the key to the era of prosperity.

The cheap education and the offer of relatively large scholarships became one of its appeals. There are at least two categories of college financing. Firstly, the students who get a scholarship entirely from the departure, while living there, until his return. Secondly, the students who received the scholarship are not full or partly, where in the first year only get a scholarship in the form of free tuition-free, and in the second year, they must propose a full scholarship. Some other attractions to study in Egypt include the living cost is cheaper than study in Indonesia.

After Indonesia's independence (1945), the relations between Indonesia -Egypt were not just in politics. The cooperation between both country also growing into the world of education and culture. The spirit of increasing cooperation was marked by the arrival of the first grand Shaykh al-Azhar, Shaykh Abdurahman Tag, in Indonesia on August 15, 1955. He came to coincide with the 10th anniversary of Indonesia's independence. In addition to discussing the possible cooperation pioneered between Indonesia and Egypt, in that occasion grand shaykh had visited places to see the development of Islamic education in Indonesia. One of the impressive testimonies of Islamic education in Indonesia, which Shaykh al-Azhar admits is his admiration for the special education institution of the daughter founded by Rahmah Yunusiah in Padang. Grand Sheikh acknowledges that education for Indonesian women is more advanced than education for women in Egypt and other Arab countries.

Two months later, on October 10, 1955, as a further step of cooperation, signed a text of cultural cooperation between Indonesia and Egypt. Signatories from the Indonesian side are represented by Foreign Affairs Minister Ad Interim Burhanuddin Harahap and the Egyptians are the Egyptian Ambassador to Indonesia Ali Fahmi Amroussi. This cooperation includes the exchange of lecturers and teachers between Indonesia and Egypt. It also agreed on student exchanges, ease of learning, comparative courses in education, culture and the arts [4].

In 1957, Grand Shaykh Al Azhar Abdurahman Tag as an appreciation to educational pioneer for women in Indonesia invited Rahmah el Yunusiah (Padang) to visit Egypt. What has been done el Rahmah Yunusiah has inspired al Azhar to establish Kulliyatul Banat (Faculty of Princess) in al Azhar. Previously, the Al Azhar College has not provided special education services for women, and since then Al Azhar began to accept female students. As a form of 
appreciation, Rahmah el Yunusiah was given the title of "shaykhah" by Grand Sheikh Al Azhar and was the first woman to be given the title by al Azhar University [5].

In 1958, another Indonesian Muslim religious leader Haji Abdul Malik Karim Amrullah or often known as Hamka was invited to Egypt at the invitation of Secretary-General of the Islamic Congress, Anwar Sadat on 13 January 1958. Hamka was invited to deliver the lecture of the Jamiyah Syubhan Muslimin Secretariat with the theme "The Influence of Muhammad Abduh's Thought in Indonesia and Malaya." Many scholars who came to the event included Grand Sheikh's deputy Al Azhar Mahmoud Syaltut. At Hamka's remarkable lecture, Hamka was granted the title of Doctor Honoris causa in the field of religious science and Islamic Philosophy. A year later, on April 28, 1959, Al Azhar again gave doctor Honoris Causa to the Deputy Prime Minister of Indonesia Idham Chalid. Next, April 24, 1960, Al Azhar gives the title back Doctor Honoris Causa to President Soekarno by Grand Sheikh Al Azhar Mahmoud shaltut.

In addition to actively giving awards to the best sons and daughters of Indonesia in the field of education and progress of Islam, Egypt symbolized by the presence of Grand Sheikh Al Azhar also made a visit to Indonesia. After the first visit by Grand Shaykh Al Azhar Abdurahman Tag (1955), the visit was followed by the next Grand Shaykh like Mahmoud Syaltut (1961), Muhammad El-Fahham (1971), Abdul Halim Mahmoud (1976), Muhammad Abdurahman Baishar (1981) Gad al-Haq Ali Gad al-Haq (1995), Muhammad Sayyid Tantawi (2006).

The frequent visiting of Grand Sheikh Al Azhar was answered by visiting of several Government of Indonesia there. The Indoneisa visiting was not only done by the Minister of Religious Affairs, but also by the President of Indonesia. Several visits can be mentioned: Indonesia's first delegation was led by Agus Salim (consisting of AR Baswedan as Deputy Minister of Information, Nazir Sutan Pamuncak as State Department Officer Rasjidi as Secretary General of the Ministry of Religious Affairs, General Abdul Qadir as Senior Officer of the Ministry of Defense) in 1947; Presidential Advisory Visit of Sjahrir (5 August 1947); Rasjidi for the opening of the Indonesian Embassy in Egypt where Rasjidi was the first Indonesian Ambassador (25 February 1950); First visit of President Sukarno accompanied by Minister of Religious Affairs KH Masjkur (18-24 July 1955); followed by subsequent President Sukarno's visits $(1958,1960,1961,1964,1965)$; visits to Egypt were also followed by President Suharto (1977) and (1998).

In the field of education began on October 10, 1955, with signed cultural cooperation between Indonesia and Egypt by the Indonesian representative by Foreign Minister Ad Interim Burhanuddin Harahap and the Egyptian Ambassador in Indonesia by Ali Fahmi Amroussi. This cooperation includes the exchange of lecturers and teachers between Indonesia and Egypt. This cooperation continues to be nurtured by both parties by visiting each other from the University of Al Azhar and the Ministry of Religious Affairs of Indonesia.

In 1995 Jakarta conducted a Seminar on Indonesia-Egypt Relations. The seminar was held to commemorate the 50th anniversary of the Indonesia-Egypt relations (1945-19950. Several evaluations and efforts to enhance cooperation between the two countries in education and culture were discussed. The seminar was followed by a Seminar in Cairo in 1997. One result and follow-up of the two seminars are the Indonesian government will build a dormitory for students in the Azhar campus environment. Agriculture is an Indonesian government grant to Al Azhar for his services to educate the children of Indonesia.

\subsection{Indonesia students in Egypt now}

In 1997, the number of Indonesian students in Egypt recorded approximately 3000 people. By the time we visited Egypt (2017), according to the information of the consulate officers we 
had met, the number of Indonesian students in the Arab Republic of Egypt was approximately 4000. This number is mostly students at Al Azhar University. Just a few Indonesian students did not go to Al Azhar University, like the Cairo University for public studies such as medicine. At the time. The total number of Indonesian students can be mapped, for S3 level as many as 30 people; S2 as many as 150 people; and the rest undergraduate education.

The attractiveness of Al Azhar University for prospective students of Indonesia, because Egypt is a reference of modern Islamic education and Al Azhar University is the oldest Islamic university in the Muslim world. Another attraction is the cheap of living costs. Besides, many scholarships are offered for Islamic students from all over the world available in Egypt. Especially for the cost of living, according to the writer during this visit (2017), the cost of living for students in Egypt can be cheaper than the cost of living students in Jakarta (Indonesia). Naturally, Egypt can be considered an affordable place of study. The other special thing, there is a special rate for students and students there is a special offer price to go back to EgyptIndonesia for student carded Egyptian students, which according to the news of Indonesian students there can be half price compared with ordinary people who do the non-student trip.

Most Indonesian students studying in Egypt take religious studies. As the oldest institution of Islamic higher education, then Al Azhar is considered as the axis of Islamic scholars of the world. Therefore, naturally, the people of Indonesia, especially from the santri and pesantren assume that Egypt became the mecca of Islamic education in modern colors. Not to mention, the grave of the great cleric Imam Syafi'i is buried in Egypt anyway. It is complete that Egypt is considered the center of Shafi'i fiqh madhhab.

One of the performances of students in Egypt, According to Azra, the level achieved by Indonesian students is less than $50 \%$. This data shows a picture of the performance of Indonesian students in studying in Egypt. There are some obstacles faced by Indonesian students in Egypt. Firstly, language difficulties. Because in the process of learning more widely used the market language ('ammiyah) is perceived differently from the Arabic fushah taught in Indonesia country. Besides, the schedule of non-strict learning activities that cause the child is not prosecuted to follow the defender jaran. Another factor is that most Indonesia students in Egypt are students with the average family background who are not wealthy. So those students easily tempted to look for additional money [6].

Today many alumni of Al Azhar who have returned to Indonesia and become figures both in the field of religion science and society. Some are professors in Islamic universities, some are government bureaucracies, and some are leaders of community organizations. Some of Egypt's graduate doctorates include Prof. Quraiys Shihab (UIN Syarif Hidayatullah), Dr. Muhlis Hanafi (Head of Lajnah Pentashihan Mushaf Al Qur'an), Dr. Abdul Ghofur Maemun (Pesantren Sarang Rembang), Huzaemah T. Yanggo, Dr. Muhammad Zainul Majdi (Provincial Governor of NTB), Prof. Azman Ismail (High Priest Mosque of Baiturrahman Banda Aceh).

\subsection{Egyptian education and it's implications in Indonesia}

Since Muhammad Abduh was involved in the educational process at Al Azhar University (1894-1905), the intensity of the Islamic Education reform movement began. Abduh proclaimed the necessity of opening the doors of ijtihad at Al Azhar University. The passion of the intellectualism movement at Al Azhar University has made Muslim societies in various countries make Egypt a model of modernizing Islamic education in other Muslim countries, including Muslims in Indonesia. The policy direction of the Ministry of Religious Affairs is inclined to make Egypt a role model for the development of modern Islamic education and universities in Indonesia. Al Azhar University's educational format is almost entirely used as a 
model for the development of study programs and faculty throughout IAIN and UIN in Indonesia.

The color of the modernization of the education of al-Azhar University of Egypt can be indicated in several ways, among others: Firstly, the shift of mainstream Al Azhar ideology from Shiism to orthodoxy of Sunni ideology; secondly, the controversy of Islamic civilization with the French civilization impact of the Napoleon Bonaparte invasion of France brought renewed education to Al-Azhar; Thirdly, the emergence of figures and ideas of renewal of thought in Al-Azhar in Egypt was spearheaded by Muhammad Ali Pasha, Muhammad Abduh, and Muhammad Rashid Ridha who attempted to reform and modernize education in Al-Azhar by incorporating curriculums from the West [7].

The Al Azhar change makes this institution increasingly become a reference for developing Islamic universities. With some renewal manhaj of Al Azhar and its alumni have established themselves as leading in the modernization of Islamic thought and education. Al Azhar with his open understanding has made space for the creation of a rational Islam in Muslim countries. Egypt became an important country as one of the references in developing and giving direction to the modernization movement of Islamic education.

Currently, Egypt together with Turkey is becoming a model of educational modernization for Muslim countries. It is acknowledged that Egypt has a big role in advancing Islamic education in Indonesia. Distinction alumni of Al Azhar University when compared to alumni from other Middle Eastern countries, such as Saudi Arabia, are very clear. Egyptian Alumni tend to have a diverse range of turbos comparing. Egyptian alumni tend to speak fluently about various views of the jurisprudence of fiqh and choose from various madhhab. While Saudi Arabian alumni tend to master in generic sciences that are more related to the main sources of religion, namely the Qur'an and al-Hadith so impressed, not rich in discussion an inter-religious interpretation.

The modernization of education of Al-Azhar University has so far succeeded in carrying out the Islamic wasathiyah mission which has been carried out in more than a thousand years. According to Al Azhar alumni in Indonesia, this role has proven to be warmly welcomed throughout the hemisphere. That's because the methods developed and taught in Al Azhar University are built on two main pillars; textual sciences based on Al-Quran and Hadith and contextual sciences that are in line with human reason. Thus, Al-Azhar alumni believe that revelation is not contrary to reason. Al-Azhar also teaches the culture of respect for diversity, develops a life of harmony and respects opinions and principles in inter-religious relations.

The mission of moderate Al-Azhar University has been an inspiration for Indonesia. The last alumni meeting of Al Azhar University in Indonesia (2017) in Mataram Nusa Tenggara Barat (NTB) still depends on the mission of moderatism as the general commitment of Al Azhar Alumni in Indonesia. The seven commitments include: 1) expanding Al-Azhar alumni network all over the world, to jointly and combating extreme and radical thinking; 2) developing contemporary religious discourse underlying the harmony of human life, away from the utterance of hatred and violence, respect for fellow human beings, preserving the honor of the soul, loving the country and defending the state, and reinforcing the moderate and tolerant attitude; 3) Conducting training of the dai in facing the phenomenon of extremism, religious radicalism, and fanaticism, as well as related issues; 4) massively disseminate the Al-Azhar clerical response to issues that threaten moderate religious life utilizing information and communication technology; 5) disseminating Asyari's theology in the matter of a creed which is the protective bulwark of Islam from extreme and radical thought and ideology; 6) calls for caution in accepting religious fatwas existing in social media. The religious fatwa should refer to authoritative sources taking into account the conditions and customs of the local community; 
7) establish a special committee to follow up on the resulting decisions and recommendations $[8]$.

In addition to the Al Azhar University campus in the field of religious develop moderate Islam, Al Azhar University also began to step by developing in the field of general science that is not only limited in the field of religious sciences but also open the general sciences. Precisely, in the time of Shaykh Mahmud Syaltut, Al Azhar University no longer confines only to pure Islamic sciences but also began to open the general faculty. In 1961, Law no. 103 of 1961 which establishes the faculties of the general branch of science, such as medical faculty, commerce, engineering, agriculture, pharmacy, and others that we can see today. As a modern university, Al Azhar also opened a classroom model classified into two faculty groups: 'Ilmi (science) and Adaby (religion). The "central building" of the two faculties is also separate, the 'Ilmi' faculties occupy most of the Nasr City area. While the Adaby generally is in the area Hussein, both are still in the city of Cairo.

Although there is a grouping of faculties, it is not Al Azhar's intent to separate the study of general and religious fields, but rather as an attempt to specialize in the field of study for its students. Besides, Al Azhar also began to open high education for women. In 1957, Grand Shaykh Al Azhar Abdurahman Tag inspired women Rahmah el Yunusiah (Padang) established Kulliyatul Banat (Faculty of Princess) in al Azhar. Since then, Al Azhar also provides a special female faculty (Kulliyatul Banat) which is separated from the male students (Banin).

Movement of the development of a general study program at Al Azhar University was later followed by Islamic Universities in Indonesia. It's just that the opening of the general faculty was only started 40 years later. Since 2002, After Indonesia entered several reforms IAIN in Indonesia was upgraded to the Islamic University of Indonesia. Since then, UIN began to develop medical and health faculties. Starting from UIN Syarif Hidayatullah Jakarta. To support the development of UIN in integrating the aspects of science, Islamicity, and Indonesian. To accelerate the integration, the Senate Session of UIN Syarif Hidayatullah Jakarta on December 30, 2002, considers the importance of opening a new course in Medicine and Health. Beginning in the academic year 2004/2005 UIN Syarif Hidayatullah Jakarta through the Faculty of Medicine and Health Sciences began to accept new students of the Program of Public Health and Pharmacy.

Along with the opening step of the general study program conducted UIN Syarif Hidayatullah, UIN Malang and UIN Makasar also opened the faculty of medicine. Later some UINs are preparing to take the same steps as UIN Sunan Kalijaga Yogyakarta. In 2017, three UIN leaders expressed a desire to open medical faculty when meeting with Vice President Jusuf Kalla at the Vice President's Office in Jakarta. The three UINs are UIN Sunan Ampel Surabaya, UIN Raden Fatah Palembang, and UIN Syarif Kasim Riau [9].

\section{Conclusion}

From this research, I found some important notes which become the conclusion of this research. Firstly, education in Egypt, especially at Al Azhar University teaches Islam wasatiyah which corresponds to the culture of Indonesia's diversity. A moderate outlook becomes a trademark of Al Azhar University alumni. This alumni model is needed to guard the diversity in Indonesia as one of the pillars of the unitary state of the Republic of Indonesia. Secondly, Al Azhar University alumni have contributed significantly to advancing Islamic moderatism in 
Indonesia. It is realized with the alumni's gait in advancing Islamic education such as madrassas and Islamic colleges that prioritize moderate Islam.

This study recommends that firstly the good relations of Indonesia of Egypt need to be maintained and institutionalized in advancing modern Islam in Indonesia. Secondly, facing the number of successful students is still below $50 \%$, then the Indonesian government needs to make a breakthrough step to accompany the Indonesian student's need in Egypt like language strengthening, living expenses, literary mastery, and incentives for master's and doctoral degrees. Thirdly, if the student back to Indonesia, after finished their study, the Indonesian government needs to make an accommodation to the Egyptian alumni in the development of Islamic education with considering pick them being a civil servant (PNS) and the socio-political process in Indonesia.

\section{References}

[1] Giora Eliraz. "The Islamic Reformist Movement in the Malay-Indonesian World in the First Four Decades of the 20'h Century: Insights Gained from a Comparative Look at Egypt." Studia Islamika, VoL 9, No.2, 2002

[2] Usman, "Model Deradikalisasi Narapidana Terorisme Studi Perbandingan Deradikalisasi Di Yaman, Arab Saudi, Singapura, Mesir Dan Indonesia." Inovatif. Volume VII Nomor II Mei 2014

[3] Khoirudin Nasution, "Gerakan Militan Islam Mesir dan Relevansinya dengan Politik Islam Indonesia: Studi Gerakan Ikhwan al-Muslimun," UNISIA. No. 41/XXII/IV/2000

[4] Sinbathi, Muhammad Ahmad. Hadharatuna fi Indonesia, Kuwait: Darul al-Qalam, 1982, h. 193194.

[5] Fachir, AM. Jauh di Mata Dekat di Hati: Potret Hubungan Indonesia Mesir. Cairo: Kedutaan Besar Republik Indonesia Mesir, 2010

[6] Azyumardi Azra, Jaringan Keilmuan Indonesia-Mesir, Republika, 16 Nopember 2017

[7] Tambak, Syahraini, Eksistensi Pendidikan Islam Al Azhar: Sejarah Sosial Kelembagaan dan Pengaruhnya terhadap Kemajuan Pendidikan Islam Era Moderniasisi di Mesir. Jurnal AtThariqah, Vol. 1 No. 2 Desember 2016

[8] Deklarasi Lombok Alumni Al Azhar ..., Republika.co.id, 20 Oktober 2017

[9] UIN Bisa Buka Fakultas Kedokteran, Republika.co.id, Kamis 2 Nopember 2017

[10] Sukino, Arief, "Dinamika Pendidikan Islam Di Mesir Dan Implikasinya Terhadap Transformasi Keilmuan Ulama Nusantara," Studia Didaktika, IAIN Pontianak, Vol.10 No.1 Tahun 2016 